\title{
RNA induced enhancement of wire climbing in the rat
}

ROBERT G. GIBBY AND DAVID G. CROUGH

VETERANS ADMINISTRATION HOSPITAL, RICHMOND, VIRGINIA

Rats receiving an IP injection of neuronal $R N A$ from donors trained on a wire climbing task performed significantly better over a three day learning period than did naive RNA or reagent blank controls. There were no significant differences between the naive $R N A$ and reagent blank groups.

Both positive results (Jacobson, Babich, Bubash, \& Jacobson, 1965; Babich, Jacobson, \& Bubash, 1965; Jacobson, Babich, Bubash, \& Goren, 1966; Fjerdingstad, Nissen, \& Roigaard-Petersen, 1965) and negative results (Branch \& Viney, 1966; Gross \& Carey, 1965; Luttges, Johnson, Buck, Holand, \& McGaugh, 1966) have been reported by investigators attempting to demonstrate a biochemical transfer of learning by using "trained RNA" extracted from donor rats and injected into naive recipient rats. It is the purpose of this study to explore this possibility further through the utilization of a task not employed in previous studies.

In order to find support for his theoretical model of molecular intraneuronal storage of information, Hyden (1962) taught a group of rats to climb a steeply inclined wire. Hyden concluded that rats trained on this task had a significantly increased adenine/uracil ratio of nuclear RNA and an increase in the total amount of neuronal RNA. Therefore, since wire climbing is known to produce changes in brain RNA, it is hypothesized that an injection of RNA extracted from animals trained on wire climbing would aid naive recipient animals in learning the same task.

\section{Method}

Subjects. The Ss were 50 male Wistar rats, each weighing from $190-230 \mathrm{~g}$ at the time of testing. These formed two major groups, the RNA donor and the RNA recipient groups. There were 20 rats in the donor group which was then further subdivided into two additional groups. One was the Trained Donor group, which consisted of 10 rats trained to criterion on the wire climbing task and the other was the Naive Donor group, which consisted of 10 rats not trained on any task. The remaining 30 animals (who were litter mates) constituted the recipient groups. These were formed into three experimental groups of 10 animals each. Experimental Group 1, the trained RNA recipients, received injections of RNA extracted from the brains of Ss trained on the wire climbing task. Experimental Group 2, the naive RNA recipients, received injections of RNA extracted from the brains of nontrained rats. Experimental Group 3, the reagent blank recipients, received an injection of the reagent blank solution.

Apparatus. The test apparatus was a $43 \times 75 \times 16$ in. box painted flat black and open on one side. A rubber insulated wire, 1/8 in. in diameter, extended at an angle of $38^{\circ}$ from a low to a high platform. Distance along the wire was 40 in.

Procedure. The donor animals for the trained RNA group (TRNA) were food deprived for $48 \mathrm{~h}$, and then were given three weeks of training on the wire climbing apparatus. Twice daily (morning and afternoon), each rat was placed on the wire at a point approximately 2 in. from the platform 30 times, and was aided in reaching the platform on each trial. Once $S$ had learned to balance on the wire, he was unaided in reaching the platform. As ability to climb increased, $S$ was placed on the wire farther from the platform until finally he could start from the bottom platform. Upon reaching the top platform the $S$ was always rewarded with a $45 \mathrm{mg}$ Noyes food pellet. The rat was considered trained when he reached a criterion of 10 unaided round trips (from bottom to top and back) within a $15 \mathrm{~min}$ period on two successive days.

Upon reaching the criterion the Ss were sacrificed. Within $3 \mathrm{~min}$, the entire brain was removed, and then the olfactory lobes and $1 / 4 \mathrm{in}$. of the frontal lobes were removed and discarded. Next, a cut was made on a line connecting the superior colliculf to the rostral end of the pons, and the tissue posterior to the section was discarded. The cold phenol method (Babich et al, 1965) was employed to extract the RNA from the remaining brain tissue. Sufficient saline was added to the obtained RNA precipitate to make a total of $10 \mathrm{cc}$ of RNA solution, so that each recipient animal could receive a $1 \mathrm{cc}$ injection (the equivalent of RNA extracted from one donor brain). In a similar manner, the RNA was obtained from the brains of the naive (untrained) donor animals, and saline was added so as to result in $10 \mathrm{cc}$ of naive RNA solution. The concentration of RNA in each of the extracts was $.7 \mathrm{mg} / \mathrm{cc}$ saline solution based on a yeast RNA standard as measured by a Hitachi spectrophotometer (Model 139) at $260 \mathrm{~m} \mu$.

Each of the $10 \mathrm{Ss}$ in Experimental Group 1 (trained RNA recipients) was injected IP with 1 cc of the RNA extracted from the brain tissue of the trained donors. At 12, 36, and $60 \mathrm{~h}$ following the injection, they were tested on the wire climbing task. The test consisted of placing the $S$ on the wire in such a way that the forepaws grasped the wire and the hind paws straddled the wire; then, the $\mathrm{S}$ was released. The response was regarded as being successful if $S$ moved to either platform or remained on the wire for $15 \mathrm{sec}$. Thirty trials were given with a 15 sec intertrial interval.

Each of the $10 \mathrm{Ss}$ in Experimental Group 2 (naive 
Table 1. Cumulated scores, mean cumulative scores, and total ranks for groups by day.

\begin{tabular}{|c|c|c|c|c|c|c|c|c|c|}
\hline \multirow{2}{*}{$\begin{array}{l}\text { Group } \\
(\mathrm{N}=8)\end{array}$} & \multicolumn{3}{|c|}{ Day 1} & \multicolumn{2}{|c|}{ Day 2} & \multicolumn{4}{|c|}{ Day 3} \\
\hline & Sc & $\mathbf{M}$ & $\begin{array}{l}\text { Total } \\
\text { Ranks }\end{array}$ & $\mathrm{Sc}$ & $\mathbf{M}$ & $\begin{array}{l}\text { Total } \\
\text { Ranks }\end{array}$ & Sc & $\mathbf{M}$ & $\begin{array}{l}\text { Total } \\
\text { Ranks }\end{array}$ \\
\hline Trained RNA & 45 & 5.62 & 19.0 & 179 & 22.38 & 21.5 & 364 & 45.50 & 22.5 \\
\hline Naive RNA & 20 & 2.50 & 13.5 & 89 & 11.12 & 15.0 & 179 & 22.38 & 13.0 \\
\hline Reagent Blank & 21 & 2.62 & 15.5 & 74 & 9.25 & 11.5 & 172 & 21.50 & 12.5 \\
\hline
\end{tabular}

RNA recipients) was injected IP with 1 cc of the RNA extracted from the brain tissue of the naive donors. They were tested in a manner similar to that above at 12, 36, and $60 \mathrm{~h}$ intervals following the injection. Finally, each of the $10 \mathrm{Ss}$ in Experimental Group 3 (reagent blank) was injected IP with $1 \mathrm{cc}$ of a reagent blank solution, which was prepared in exactly the same manner as the RNA solutions from the trained and naive donor animals, except that no brain tissue was included in its preparation.

\section{Resulis and Discussion}

The number of successful responses were obtained for each group of Ss in the manner previously described. These were then cumulated for each of three experimental days. These data are summarized in Table 1 , together with the respective mean cumulative scores and cumulative ranks for each day for each group.

In order to determine whether or not the three groups differed significantly in total successful responses over the three day period, the cumulated scores for the three days first were analyzed by means of the Friedman test (Siegel, 1956). The obtained $\mathrm{X}_{\mathrm{r}}^{2}$ was 7.00 , which is statistically significant $(p<.05)$; the three experimental groups differed significantly in cumulated successful responses over the three day experimental period.

In order to discover the specific group differences, the data were next analyzed by means of the Wilcoxon test (Wilcoxon \& Wilcox, 1964). The difference in rank between naive and trained RNA groups was 8 , between the trained and reagent blank groups 10, and between between the naive and reagent blank groups, 2.

The differences between the Ss receiving trained RNA and those receiving the reagent blank as well as those receiving the naive RNA were both statistically significant for the cumulated three day scores $(p<.05$ in both cases). The differences between Ss receiving naive RNA and those receiving the reagent blank were not found to be significant ( $p>.10)$. Therefore, it may be concluded that the Ss receiving trained RNA did significantly better on the experimental task than did either the Ss recelving naive RNA or those receiving the reagent blank. Those Ss receiving naive RNA did not perform significantly better than did the Ss receiving the reagent blank.
The differences between the groups by each experimental day were examined. The data were analyzed by means of the Friedman test; $X_{r}^{2}$ for Day 1 was 1.93 ( $p$ $>.05)$, for Day 2 was $7.94(p<.02)$, and for Day 3 was $6.44(p<.05)$. Therefore, it was concluded that there was no significant difference among the three groups on the first day, although there was a decided trend. However, there was a significant difference between the groups on both the second and third days.

In summary it may be concluded that: (1) The three groups differed significantly in total performance over the three day period, with the group receiving the trained RNA performing better than either the naive RNA or the reagent blank groups. There was no significant difference between the naive RNA and reagent blank groups. (2) In comparing performance by days, there was no significant difference on Day 1 , but on Days 2 and 3 there were significant differences between the groups. The Ss receiving trained RNA did better on the experimental task than did the Ss receiving either naive RNA or the reagent blank, while the Ss receiving naive RNA did not perform better than did the Ss receiving the reagent blank.

\section{References}

BABICH, F. R., JACOBSON, A. L., BUBASH, SUZANNE, \& JACOBSON, ANN. Transfer of a response to naive rat by injection of ribonucleic acid extracted from trained rats. Science, $1965,149,656-657$.

FJERDINGSTAD, E. J., NISSEN, TH., \& ROIGAARD-PETERSEN, $\mathrm{H}$. H. Effect of ribonucleic acid (RNA) extracted from the brain of trained animals on the learning of rats. Scand. J. Psychol., 1965, $6,1-6$.

HYDEN, H., \& EGYHAZI, E. Nuclear RNA changes of nerve cells during a learning experiment in rats. Proc. Nat. Acad. Sci.,1962 $48,1366-1373$.

JACOBSON, A. L., BABICH, F. R., BUBASH, SUZANNE, \& GOREN, CAROLYN. Maze preferences in naive rats produced by injection of ribonucleic acid from trained rats. Psychon. Sci, 1966, 34.

JACOBSON, A. L., BABICH, F. R., BUBASH, SUZANNE, \& JACOBSON, ANN. Differential approach tendencies produced by injection of RNA from trained rats. Science, 1965, 150, 636-637.

LUTTGES, M., JOHNSON, T., BUCK, C., HOLLAND, S., \& McGAUGH, J. An examination of "transfer of learning" by nucleic acid. Science, $1966,151,834-837$.

SIEGEL, S. Nonparametric Statistics. New York: McGraw-Hill, 1956. WILCOXON, F. \& WILCOX, R. A. Some rapid approximate statistical procedures. Pearl River: Lederle Laboratories, 1964. 